\section{Innsiktsfullt om flyktninghelse}

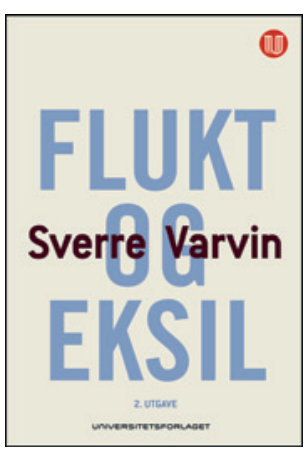

Sverre Varvin

Flukt og eksil

2. utg. 261 s, ill. Oslo: Universitetsforlaget,

2015. Pris NOK 329

ISBN 978-82-15-02418-9

Varvins lærebok er skrevet for studenter i helse- og sosialfag og tar sikte på å forberede fremtidige helsefagarbeidere på møtet med mennesker som har flyktet til Norge. Denne reviderte og omarbeidede utgaven består av tre deler: Flukt, Traumatiseringens konsekvenser og Livet i eksil. Den første delen setter søkelyset på bakteppet for migrasjon, migrantenes opplevelser forut for, under og etter en flukt og migrasjon $i$ et historisk og folkerettslig perspektiv. I de neste to delene omtales de psykologiske konsekvensene av traumatiseringen samt mottak og helsehjelp til migranter etter ankomst Norge.

Boken tar utgangspunkt i forfatterens kliniske møte med en håndfull migranter, som vi følger gjennom hele teksten. Språket er lett tilgjengelig også for lesere som ikke fra før er fortrolig med fagfeltet. I de tilfellene der forfatteren tyr til fagterminologi og psykologiske begreper, er disse forklart i egne tekstbokser. I teksten har forfatteren fortløpende innarbeidet et utvalg av referanser til vitenskapelige publikasjoner som gir leseren mulighet for å fordype seg videre.

Flukt og eksil fremstår svært oppdatert og grundig. Forfatterens bruk av kasus fremhever kompleksiteten innen flyktninghelsearbeid på en svært virkningsfull måte. Kasusene gir fagområdet ansikt og gjør det lettere for leseren å leve seg inn i tematikken. Betydningen av å møte hver enkelt migrant individuelt og å forstå deres helt unike historie er overbevisende formidlet. Dessverre opplever jeg tidvis at kompleksiteten går på bekostning av oversiktligheten og systematikken i teksten, bl.a. oppleves disposisjonen i del 2 noe utydelig. Forfatteren balanserer på en vanskelig egg mellom fag og popularisering. Jeg synes at forfatteren jevnt over mestrer denne øvelsen svært godt, selv om jeg ikke alltid helt kjøper hans argumentasjonsrekker og konklusjoner uten gjennom å skjele til referansene innarbeidet $i$ teksten.

Med bakgrunn i dagens migrasjonssituasjon i Europa vil legers kunnskap om flyktninghelse bli stadig viktigere. Jeg er overbevist om at mange medisinstudenter og leger kan ha svært godt utbytte av denne boken. Den setter migrasjon inn i et større perspektiv, formidler innsiktsfullt om mennesker på flukt og vil være er et godt supplement til mer systematisk litteratur innen traumatologi og psykiatri.

\section{Jon Magnus Haga}

Lege/stipendiat, Nasjonalt kunnskapssenter om vold og traumatisk stress (NKVTS)

\section{Om å møte det uhelbredelige}

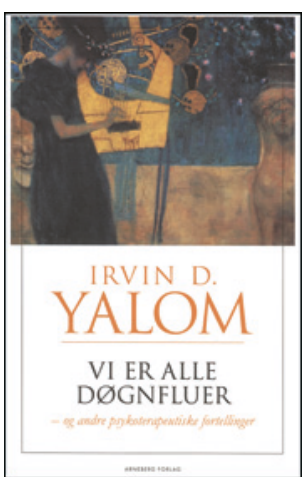

Irvin D. Yalom

Vi er alle døgnfluer

$\mathrm{Og}$ andre psykoterapeutiske fortellinger.

234 s. Oslo: Arneberg forlag, 2015.

Pris NOK 299

ISBN 978-82-8220-101-8

Denne boken tar oss med inn i psykiaterens og psykoterapeutens arbeidsrom. Vi får ta del i ti dialoger som utspiller seg mellom forfatteren og pasienter av ulik alder og kjønn som alle står oppe i en eksistensiell krise i sine liv. De fleste har kreft eller annen dødelig sykdom. De kommer fra fjern og nær, alle for å få dele sin historie og sitt perspektiv på det liv de har levd og det som nå skal komme.

Forfatteren Irvin D. Yalom er en svært kjent amerikansk psykiater. Det illustreres også ved at disse pasientene kommer reisende langveis fra og er villig til å betale godt for en eller noen få samtaler med denne mannen. Man kunne derfor frykte en serie kasuistikker fra en amerikansk overklasseverden uten generell interesse. Slik er det ikke. Alle møtene gir en dypere forståelse av noe allmennmenneskelig som har verdi langt utover hva som kan virke forløsende for disse pasientenes forståelse av eget liv. Terapeuten møter dem med en åpen undring og vilje til ny forståelse og en villighet til også å bruke erfaringer fra eget liv. Han illustrerer godt prinsipper i eksistensiell og psykodynamisk psykoterapi.

Først og fremst viser samtalene betydningen av relasjonen mellom pasient og terapeut og den store verdien det har for mennesker i krise å få dele sin historie og sin fastlåste opplevelse av hvor veien videre skal gå med en terapeut som kan bære at det nå går mot slutten. På denne måten blir pasienten mer i stand til å håndtere siste fase i livet på en konstruktiv måte - både for seg selv og sine nærmeste. I en tid hvor psykiatrien blir mer og mer symptomorientert er denne boken en særlig viktig påminnelse om at det mange av våre pasienter trenger ikke er «quick-fix»-pregede intervensjoner på enkeltsymptomer, men hjelp, kort- eller langvarig, til å se hvor de er i sine liv og til å gå videre henimot en meningsfull avslutning.

\section{Per Vaglum}

Professor emeritus, Avdeling for medisinsk atferdsvitenskap Det medisinske fakultet

Universitetet i Oslo 